\title{
Mapping Trajectories of Attention to Drug Related Issues in Estonian Main Dailies
}

\author{
Marianne Paimre \\ Department of Law, University of Tartu, Tartu, Estonia \\ Email: marianne.paimre@ut.ee
}

Received 5 June 2015; accepted 26 July 2015; published 29 July 2015

Copyright (C) 2015 by author and Scientific Research Publishing Inc.

This work is licensed under the Creative Commons Attribution International License (CC BY). http://creativecommons.org/licenses/by/4.0/

(c) (i) Open Access

\section{Abstract}

Illicit drugs have been a burning social issue in Estonia over the last fifteen years. Estonia has taken the lead in Europe with regard to drug-related deaths and prevalence of HIV among injecting drug users. Experimental drug use among Estonian students is more widespread than the European average. It is important to study press coverage, because according to agenda setting theory, the media plays an important role in influencing the salience of social issues on the public agenda. The aim of this article is to map fluctuations in attention received from Estonian two major dailies to different drug related issues during the last 25 years. The author focuses on issues highlighted in national and international drug reports such as drug addiction, drug related crime, spread of HIV among addicts, drug-induced deaths, drug problem in schools etc. Content analysis of almost 1000 press articles reflecting drug problems in Estonia was carried out from 1990 to 2014. The study revealed that since 1995, attention received from the major newspapers to drug related crime has been high and quite stable compared to other drug issues. Press interest with regard to problem drug use and HIV was notice a bleat the turn of the millennium and in the beginning of the new century, but almost lost by 2014. More intense periods of coverage were triggered by specific events. Only a few articles have reflected drug induced death despite the fact that Estonia is the undisputed leader in the EU regarding this indicator. This reflects that the coverage was not been in line with the drug situation in Estonia. It seems that the attention of the press depends rather on newsworthiness of the issue and the agenda setting processes.

\section{Keywords}

Media Attention, Newspapers, Changes, Drug Issues, Content Analysis, Eastern Europe

\section{Introduction}

Drug addiction has been one of the burning social issues in Estonia over the past decades. By today, Estonia has 
taken the lead in Europe with regard to drug-related deaths and prevalence of HIV among injecting drug users. Experimental drug use among Estonian students is more widespread than the European average. Despite efforts at the national level, use of illicit drugs among the population has grown in the new millennium (NIHD, 2014). It has been suggested that drug problems will not diminish as long as the general public fails to recognize their importance (NIHD, 2005; Ministry of the Interior, 2014). Some blame could be placed on the media for downplaying the problem (Ibid).

According to the agenda setting theory, the urgency the public attributes to a problem is very much conditioned by the prominence the media accords to it (McCombs \& Shaw, 1972; McCombs \& Reynolds, 2002; Schäfer et al., 2014: p. 153). The print media is an important factor in raising awareness about social issues including drugs (Bell, 1985; Coleman, 1993; Edwards, 1995; Crano \& Burgoon, 2002; McQuail, 2010). Major newspapers could play a prominent role in determining public opinion about illicit drugs and shaping relevant public policies (Fan, 1996; Lawrence et al., 1999; Blood et al., 2003; Watts, 2003; Hoffman \& Slater, 2007). Thus, it is necessary to explore how drug issues are reported in national dailies.

Several scholars have studied press coverage on illicit drugs across the world. The multidimensional and complex nature of the research question has given rise to a variety of methodologies and approaches. Many scientists have analyzed the context, in which illegal drugs have been represented in the media as well as the prevalent attitudes regarding drug use (e.g. Törrönen, 2004; Manning, 2006; Bright et al, 2008; Hellman, 2010; Hughes et al., 2010). Other researchers have focused on the interconnections between media coverage, public opinion and public policies (Shoemaker et al., 1989; Deseran \& Orcutt, 2009). Qualitative studies concentrating on some significant case have been rather commonplace (McArthur, 1999; Lawrence et al., 1999; Elliott \& Chapman, 2000). Scientists have often blamed the media for the sensational, biased and one-sided angle characteristic of their drug accounts which could exert a disorienting effect on the public perception of the issue (Craig, 1981; Murji, 1998; Chermak, 1997; Manning, 2006; Noto et al., 2006; Bright et al., 2008; Taylor, 2008). Only some scholars have concentrated on changes in media coverage of drug issues (e.g. Fan, 1996; Hellman, 2010; Hughes et al., 2010). There is lack of longitudinal studies in this field. This article hopes to fill the gap in this respect.

In the US, Gonzenbach (1996) tracked trajectories of attention to the whole drug issue provided by the public, government, the president and the media in the 1980s using a five-stage model of issue attention cycle introduced by A. Downs. However, the US has faced the drug problem already many decades by then. Thus he does not focus on formation of the drug issue, but instead takes a period when the cycle emerged clearly. In Estonia, it is possible to study the development of the mediated drug discourse from the very beginning, because drugs entered the public agenda relatively late compared to the Western societies, only in the 1990s (Paimre, 2013). In this study, simplified version of attention cycle (McComas \& Shanahan, 1999) with three phases of media interest (waxing attention, maintenance, and waning attention) is used in order to explore changes in press attention to drug problems in Estonia. It could be argued that issue cycles (see e.g. Djerf-Pierre, 2011) are under scrutiny in this article.

The aim of this study is to map fluctuations in newspaper coverage of different issues related to illicit drugs (addiction, drug crime, spread of HIV among addicts, drug-induced deaths, drug problem in schools etc.) in post-Soviet Estonia (1990-2014). Thus the article focuses on the press coverage of drug problems, but not on the attention received by the political institutions or public. The author poses the following question: How has press concern to various issues related to drugs changed during the past quarter century? Has press attention generally been in line with real-world indicators? What kind of events has triggered "spikes"?

Some scholars have indicated to "issues" broadly defined in their analysis to the whole ecological domain (e.g. Downs as cited in Djerf-Pierre, 2011), the others have been concentrated on some single issue (e.g. Shanahan \& McComas, 1997). In this article, coverage of several sub-issues of the whole illicit drug domain is under scrutiny. When studying media coverage on drugs scholars have often focused on representations of different substances (e.g. Sznitman \& Lewis, 2015; EMCDDA, 2005; Manning, 2006). The author of this article does not concentrate on different substances, but instead focuses on the coverage of different social problems induced by (or attendant to) illicit substances and their use (e.g. drug addiction, drug related crime etc.).

\section{Sample and Method}

\subsection{Sample}

Two national dailies with the largest circulations, Postimees (PM) and Eesti Päevaleht (EPL) were selected for 
the research. Their predecessors Edasi and Noorte Hääl were under scrutiny in 1990. Articles from 1990-2000 were retrieved by reviewing publications stored in the library with the aim of identifying all the stories reporting on drugs in Estonia. By 2000 most of the print newspapers had also developed their online editions and as of 2005 it became possible to use online keywords search.

The search results were extracted for the sample to include only stories with substantive content on illicit drugs focusing on the relevant situation in Estonia. If the article featured both in the print and online paper, it counted as one. All the types of articles (editorials, news, opinion articles, features etc. are involved) reporting illicit drug problem in Estonia were included. All together 962 articles were analyzed from the period 1990-2014.

\subsection{Method}

A formalized content analysis was used as the method in this study (Riffe et al., 2005). Quantitative analysis of media texts can enable large samples to be analyzed and thereby reducing the potential for sampling bias (Hansen, 1998; Hughes et al., 2011: p. 286). All the 962 articles were analyzed according to coding rules developed by the author. The main categories were the themes of articles (e.g. addiction; spread of infectious diseases; drug problem in schools; cannabis regulation; drug related crime; prevention; some other topic) and sub-topics. The author's main interest was to find out how many articles on various subjects were published in various years. Additionally, categories such as sources of information (e.g. government, parliament, police, court, treatment centres, NGO-s, media, citizens etc.), types of the article and level of the problem were used. $10 \%$ of articles ( $n$ $=96$ ) were tested for reliability by the other coder. Value of Scott's $\pi$ was 0.88 .

\section{Overview of the Development of Drug Related Issues in Estonia}

With a view to comparing and contrasting the changes in the media coverage of the Estonian drug situation, the author firstly offers a short overview of the development of the drug related problems in Estonia. Illegal drugs became more widespread in Estonia only as late as a couple of decades ago. The number of problem drug users went up, drug-related crime took off, students started to express a closer interest in experimenting with illegal drugs in the 1990s (PHARE, 1998). There were many reasons contributing to the spreading of illicit drugs in Eastern-Europe e.g. more travel opportunities opened up, illegal substances became more accessible etc. (Ibid).By the turn of millennium, all the indicators reflecting drug problems have increased considerably. Drug problems in Estonia that have been mentioned repeatedly in the international and national reports have been discussed in more detail below.

Problem drug use. By mid-1990s data collected from medical institutions revealed a significant rise in problem drug use. 24.5 drug users to a hundred thousand inhabitants were registered in 1995 by hospitals. By comparison the corresponding average figure for 1960s was only 3.5 and for 1970s 6.2 (PHARE, 1998: p. 31). By 1996 the number had risen to 51.6 and by 199772.8 already (Ibid). The baseline in drug statistics has shifted considerably over time making it difficult to compare the earlier indicators with the more recent ones. In the 21th century, the use of opiates and amphetamine in Estonia has been significant (UNODC, 2011: p. 52; UNODC, 2013; OECD, 2014: p. 53). Estonia has been among the EU countries with the highest rates of injecting drug use (EMCDDA, 2014: p. 47).

Spread of HIV and other diseases. The above issue is closely linked to the transmission of infectious diseases among addicts. Isolated instances of HIV carriers among IDUs were recorded already as early as in 1997 and 1998 (NIHD, 2009). At the turn of the millennium there was an upsurge in recorded numbers of IDUs with HIV. The incidence figure for 2000 was 354 compared to 1340 in 2001 (NIHD, 2011), which is frightfully many for a country with a population of 1.3 million. By 2010 the figure has dropped to 62. Despite the government's efforts to tackle the acute problem and the recession in statistics, Estonia still tops the EU for this particular indicator (EMCDDA, 2014: p. 47; UNODC, 2014: p. 8).

Drug induced death. In the 2000s, Estonia has become Europe's run-away leader in drug deaths (EMCDDA, 2014; NIHD, 2014). The mortality rate is twice that of second placed Norway. In 2000, 31 drug induced deaths were recorded, 57 respectively in 2005. A total of 101 people died due to using drugs in Estonia in 2010 (this was 133 people in 2009). The number of drug-induced deaths in Estonia soared in 2012 (123 cases). The National Institute of Health has reported that overdoses are the predominant cause of death. Fentanyl, which is produced mainly in neighboring Russia, has been the underlying cause of death in most cases (NIHD, 2014). At 
the moment Estonia ranks 4th in the world with respect to this particular indicator (data from NIHD).

Drug use by adolescents. Experimenting with softer drugs (e.g. cannabis, ecstasy etc.) by youth has spread significantly during last decades. Only $7 \%$ of the 15 - 16 year-old adolescents has experimented with drugs according to the 1995 ESDPAD survey (NIHD, 2002: p. 18). In 1999 the indicator was 15\% already and in 2003 24\% respectively. By 2011 third (32\%) of the 15 - 16 year-old schoolchildren reported having tried some illicit drug in their lifetime which exceeds the European average (ESPAD, 2012). The spike in drug use came to a halt in 2011. Thus the problem has rapidly grown during the 1990s and 2000s, but now is finally slowing. However a new problem has emerged lately—handling of illicit drugs by minors has exhibited an upward trend in recent years (Ministry of Justice, 2015).

Drug related crime. The number of drug-related offences started to increase considerably since the second half of the 1990s. A dramatic growth in recorded drug offences occurred at the beginning of 2000s. When in 1997 only 114 offences were officially recorded (twice more than in 1995), then the corresponding figure for 2001 amounted to 2301 (data from the Ministry of Justice). After the peak year this number has not exceeded 1600 per annum. The downward trend is most likely attributable to the fact that drug abuse was no longer deemed an offence subject to criminal punishment. In 2010, 957 drug offences were registered, in 2014 was the indicator 1218 (Ministry of Justice, 2015). However, compared with the other European countries, drug seizures do not seem to be a major problem in Estonia (EMCDDA, 2014: p. 79).

Thus, almost from the nonexistence, drug problems have increased rapidly in Estonia during recent decades. The state has reacted to the drug problems since the second half of the 1990s (Paimre, 2013). The first drug prevention program was launched in 1997. In 2014, the latest drug strategy document was introduced by the Ministry of Interior (2014) which compared to previous versions of Estonian drug strategies, introduces softer measures in combating drugs.

Despite efforts at the national level, drug problems have not reduced noticeably in Estonia. Sociologists have proposed that the relatively modest success in the prevention arena can be attributed to the fact that the general public fails to recognize drug-addiction as a serious evil (Saar, 2012). The media reporting on drug issues could have some impact on this (Ibid). It is known that media content is important source of information for most people in several social issues (Sato \& Campbell, 2014: p. 20).

\section{Results of the Analysis of the Press Articles}

As indicated in the previous chapter, problems related to illicit drugs started to surface more in the newly independent Estonia at the beginning of 1990s. Yet by the summer of 1995 they had hardly ever garnered any attention in the two major national dailies, which did not correspond to the real world indicators. The press "discovered” illicit drugs in 1995 (see Figure 1). Since that time, issues related to illicit substances have been quite newsworthy for the Estonian main dailies. E.g. during the 2000s, every other day an article has appeared on drug problems in the major dailies. The coverage of various sub-issues is examined in more detail below.

Drug related crime. The bulk of analyzed articles (52\%) during 1990-2014 focused on the association between drugs and criminality. By comparison, articles on drug problem in schools comprised only $11 \%$. Drug related crime has attracted the attention of the dailies since 1995. Illicit drugs were represented only once in analyzed papers (PM 19. June 1995) in thefirsthalf of 1995, but in the second half of the year, already 64 articles appeared. Most of them (81\%) reflected drug related crimes. The surge of interest was not attributable to the growing number of registered drug related offences, but resulted from two dramatic drug-related events directly affecting Estonia. The first case was about the arrest of Estonian drug smugglers in Bangkok which generated 49 articles in PM and EPL in the second half of the year. In august 1995, criminal investigation department executives cut down the poppy crop in the field of a South-Estonian farmer which was the second most intensively covered case (with 41 articles). Selection of voices reflected the importance of the issue for Estonian journalists, e.g. the police accounted for $85 \%$ of the sources mentioned in articles in 1995, various ministries $19 \%$ and the government $8 \%$ respectively. The articles consisted mainly of news (72\%) next to occasional opinion pieces (5\%) and interviews (7\%). This was the beginning of the period of waxing press interest in respect to the subject.

By 2000 and 2005 the amount of articles on drug crime has substantially increased (139 and 125 articles respectively), thus the press concern for drug crime has reached to the maintenance phase. Routine news accounted for the majority of articles on drug crime theme (80\%). By 2010 attention by press has decreased (99 articles), but rose again by 2014 (109). Typical headlines of the new millennium regarding drug offences 


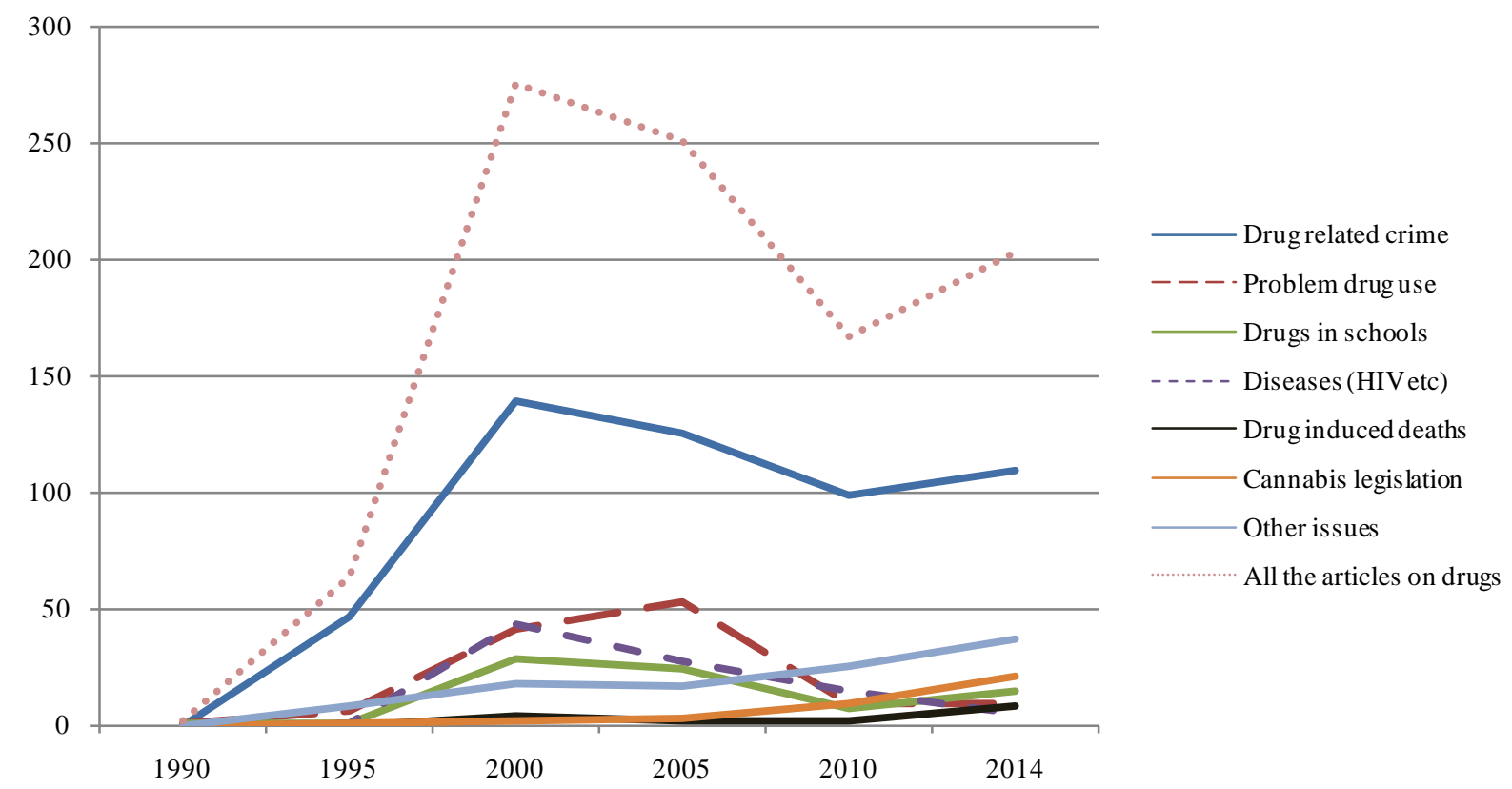

Figure 1. Trajectories of attention to drug related issues by Estonian dailies 1990-2014 ( $\mathrm{N}=962)$.

included e.g. "Smugglers of large quantities of amphetamine face punishment” (PM, 10. Sept. 2010); "Court sentenced cannabis cultivators to imprisonment” (PM, 7. Dec. 2014); "A young man high on drugs and without a driving license caused a serious accident in the calm traffic area” (PM., 30. Oct. 2014). Drug offences committed by Estonians in neighboring Finland have been especially newsworthy (e.g. PM, 8. March 2010; 8. Oct. 2010; 23. Nov. 2010, etc.). EPL, reportedly more focused on social issues, did not cover drug-related crime incidents as avidly as PM did.

In recent years, two young Estonian girls caught with nearly six kilos of cocaine in Peru in October of 2013 made the news on several occasions. Although after 1995 many Estonians have been arrested for drug smuggling all around the globe, the media coverage of this case did not fall far behind the 1995 incident in its intensity. A severe punishment (almost nine years in a Peruvian prison) awaiting for the girls in South-America seemed for the journalists to be in stark contrast with their youth and naivety (e.g. EPL, 13. Feb. 2014). In 2014, the fact that the Nigerian citizen responsible for recruiting the two Estonians as drug mules went on trial triggered the media interest for a while (EPL, 25. Nov 2014; 5. Dec. 2014 etc.).

In $91 \%$ drug related crime was discussed on state level (the state should to smth. to solve the problem). The public has supposedly inferred from the coverage brought to them over the last decades that drugs and criminal conduct are inextricably linked and that drug related crime is the most burning issue in respect to drugs in Estonia.

Addiction/problem drug use. A new and fascinating subject that captured the media's attention in 2000 was problem drug use. 41 articles focused on this aspect in 2000. All together 120 articles (13\%) covered this topic in 1990-2014. Press interest was even highest in 2005 (53 articles). 25 stories appeared on the local municipality's failed attempt to establish a day center for drug addicts in 2005. Indeed, the city of Tallinn had unveiled a plan to open a European style low threshold center, but it was derailed by the fierce opposition from local residents. The papers weighed both sides of the argument at the time. A marked change towards a more tolerant attitude of journalists to addicts originates from that period (see e.g. PM 11. May 2005 and 7. July 2005). However, by 2010 the "assistance and support" angle had lost its journalistic appeal. By 2014 the media interest has disappeared, only 10 articles appeared.

In many articles (35), addicts were portrayed as posing a serious threat to the welfare of the general public (e.g. PM, 11. Oct. 2000 and 18. Dec. 2000; EPL, 23. March 2010; PM, 14. June 2010 etc.). For instance, there were rumours going around that in order to clean their needles, addicts frequented supermarkets and used vegetables for disinfection purposes, consequently exposing all of us to AIDS and hepatitis or that they got a kick out of attacking innocent citizens in the streets with their used syringes (PM, 3. Nov. 2000 and EPL, 11. Oct. 2000). 
In 2014 there were media reports on how residents of an apartment building objected to the setting up of an automatic needle dispensing machine in their stairwell (EPL, 26. June 2014). Revealing police stats regarding the majority of thieves in Tallinn having a drug problem does very little to help local residents become more tolerant towards addicts (EPL, 29. July 2014).Such an approach was evident throughout 2010 and 2014 (e.g. EPL, 29. July 2014; PM, 14.06. 2010 etc.). In 2014 female addicts received more media attention than ever before e.g. how doctors and midwives are struggling with mothers-to-be arriving in maternity hospitals while high on drugs (e.g. EPL, 15. Dec. 2014). The proposal to replace imprisonment with addiction treatment for drug offences has been on the table since 2010 (PM, 17. March, 2010).

$21 \%$ of articles on this theme depicted drug problem as an individual concern. Main sources in addition to governmental ones (Ministry of Social Affairs, NIHD etc.) were treatment institutions (13\%), NGO's (12\%), media (10\%), citizens own information (6\%) etc. A couple of articles on addiction treatment appeared with source information provided by the drug abuse prevention conference (e.g. EPL, 19. Nov. 2010).

Spread of diseases among IDUs. In 2000, AIDS as yet another critical drug-related problem moved to the spotlight of media. $18 \%$ of articles all of a sudden devoted plenty of attention to this evil. The number of infected people that were discovered started to increase rapidly during the 2000s and the media's reaction to that was quite panic stricken (e.g. EPL, 7. Sept. 2000). A number of analytical opinion pieces and problem articles appeared (EPL, 6. Sept. 2000; PM, 7. Feb. 2000; EPL, 3. March 2000; EPL, 21. Oct. 2000 etc.). Several editorials appeared on this subject (e.g. PM, 12. Oct. 2000; EPL, 21. Oct. 2000 etc.) which indicated that the issue was quite important for the press. Besides HIV, also tuberculosis and hepatitisin relation to drug addiction were discussed. However, when examining the media coverage from 2010 and 2014, it seems that this "ghost" no longer haunts Estonia.

Contrasting to crime thematic, problems were more often discussed related to addiction and diseases on individual (24\%) or group level (13\%). However, most often the issue was discussed in the state level (40\%) which reflects the importance of the problem for the press. Articles were more analytical and profound. Important source of information besides state institutions has been the AIDS prevention center (9\%).

Drug problem in schools. This topic was under-reported until 2000 when $12 \%$ of analysed articles reflected drug problem among adolescents. The results of a research were introduced in public in 2000 (e.g. EPL, 2. Feb. 2000). In contrast to some other topics (e.g. drug related crime) scientific sources were used quite often (23\%). Scientists have been active to comment this problematic. e.g. in 2005, a sociologist (A.-A. Allaste) published several articles on adolescents and drugs (EPL, 26. Aug. 2005; PM, 2. May 2005; PM, 3. Sept.; EPL, 16. July, 2005). In 2014 drug abuse among students was discussed sporadically. Several events played an important role in activating media attention. First, cases of synthetic cannabis use made headlines as they resulted in several adolescents being admitted to the ER (PM, 7, 19, 21, 24 and 27 Nov. 2014). Secondly, the police revealed the results of the study on the drug habits of young people in Estonia. Apparently, the young turned out to be more avid cannabis users than initially suspected (PM, 4. June 2014). Thirdly, police raids in schools generated both praise as reluctant. In many cases (45\% of articles on school topic) the police was used as the main source of information. Incidentally, the fact that marijuana was grown in a vocational school's dormitory made the news (PM, 19. Dec. 2010).

Lately, the topic of school children and drugs has taken on a more sinister criminal undertone. The focus has shifted from doing drugs to dealing in drugs at schools, adults trying to take advantage of youngsters and the countermeasures introduced by the police (EPL, 13. Feb. 2014; EPL, 5. June 2014).

Drug induced deaths. Despite the seriousness of the problem, the issue has been underreported in the main dailies. Articles on drug deaths comprised only 2\% during the period 1990-2014. In 2014, eight articles were launched. The interesting fact for the journalists was that the United Nations Drug Report referred that Estonia is fifth in the world for its population in the number of drug related deaths (EPL, 15. July 2014). Already in the beginning of the year it was argued by Estonian prevention experts in press that the national prevention strategy has not worked so far and the state must now start to take action in this field (EPL, 3. Feb. 2014). The articles published in 2014 on drug-induced deaths were not too analytical, instead they conveyed mere statistical data.

Marijuana proponents' attempts at legalization. A novel and a rather distinct issue from the above is cannabis which has been generating considerable publicity for the past years now. The possible legalization of cannabis was the crux of 16 articles published in 2014.Journalists asked-how has the relaxation of cannabis laws in a number of US states affected Estonia's drug policy (PM, 1. February 2014)? On the one hand, public officials in general tend to oppose liberal drug policies (PM, 5. Feb. 2014; WPL, 23. July 2014 etc.), on the other hand, 
various cannabis activists and humanists openly call for more lenient drug reforms (PM, 1 Feb. 2014; PM, 21. Apr. 2014; PM, 15. Dec. 2014; EPL, 10. Feb. 2014 etc.). By the second half of 2014, journalists were somewhat astonished by the fact that the legalization of cannabis in some US states did not result in chaos after all (EPL, 6. Sept. 2014).

Topics compelling the latest media attention include online purchasing of narcotics constituting a criminal offence (e.g. PM, 15. Apr. 2014, 25. June 2014 and 5. July 2014) non-medical use of prescription drugs (e.g. PM 18. June 2014), minor changes in drug legislation (PM, 16. Dec. 2014), drug use in the army (PM, 24. Oct. 2014 and 25 Oct. 2014) etc.

In conclusion one can say that some issues (problem drug use, diseases) were more prone to cyclic coverage than the others (drug crime, drugs in schools). Cyclic press coverage emerged with regard to the whole drug issue. The decrease in press attention by 2010 could be explained probably by the impact economic crisis. e.g. Djerf-Pierre (2011: p. 502) has noted, that public concern for certain social issues diminish in times of economic recession. Secondly, apparently some fresh and more interesting topics caught media attention more. Thirdly, the press and the public could be tired of drug issues.

One can surmise that various evils concerning drugs enter and then fade from the media focus with the exception of drug-related crime which never loses its urgency. If the issue is new and interesting it naturally receives media attention for a while. As soon as a more novel and thrilling concern emerges, it assumes priority. For no apparent reason the indisputably pressing social ills in Estonia do not warrant must interest in the media.

\section{Discussion and Conclusions}

The results indicate that the trajectories reflecting press attention for various drug related issues are not similar. Significant fluctuations have taken place in the press interest with regard to different issues. The first problem to receive more intense coverage was drug-related crime which leaped into prominence due to sensational cases in 1995. Contrary to drug-related prevalence of AIDS in respect of which Estonia takes the lead in Europe but the media has failed to sustain interest in for too long, since 1995, drug-related crime has always been and probably will remain in the public eye. This is no surprise as delinquent behavior has been one of the favorite subjects of the press for ages. Placing the sensational aspects of drug issues centre stage has been mostly evident with regard to drug related crime. Arrests, confiscations, convictions are newsworthy for the press and seem exciting for the public. Police have been a good source of information and partner for the media in constructing drug problem. By 2000, press attention to drug crime has diminished, but has risen again by 2014 .

Press concern for other drug issues has not stayed long. Cyclical attention by the newspapers emerged especially in connection with drug addiction and HIV. By 2000, a new issue-spread of HIV among drug users led to different approaches in the media. Massive HIV recording frenzy among IDUs in 2000 and the growing panic that this illness can eventually be contracted by the so-called decent people propelled the mounting concerns to the center of attention as the year came to a close. It is interesting to note, that concern to addicts and spread of HIV did not crowd out issue of drug crime at the turn of millennium and in the beginning of the new century. The press remained focused upon problem drug use issue as well in 2005. By 2010 the print media's interest had waned considerably despite the HIV incidence rate in Estonia still being one of the highest in Europe. The current situation where drug-related issues besides crime receive little media attention does not seem to correspond to the real conditions. Media interest to drug issues seems to depend more on news values, freshness of the issue, agenda setting processes, wider economic conditions etc. than on real world indicators. Due to modest media attention on some drug issues the average Estonians indeed might not fully grasp the urgency of these problems.

More intense periods of coverage have been generally triggered by out of ordinary events. In 1995, so-called Thailand case and "poppy war" triggered news wave. In 2000, spread of HIV among IDUs caused "spike”. In 2013 and 2014, arrest of two young Estonian women in Peru made headlines in major newspapers. The experimental use of softer drugs among students has shifted to the focus of newspapers during the years in which either the findings of relevant studies and reports have been released or something else out of the ordinary has happened. Driven by the legalization of marijuana in some US states, cannabis captured the attention of Estonian newspapers in 2014. It seems that reporting on drug problems is geared more to commercialization of newsworthy events which apparently takes precedence over serving the common good by addressing critical social issues.

Coverage of drug related issues is, to a considerable degree, dictated by the profit-making ambitions of journalism characterized by the greatest regard for newsworthiness. Novelty, dramatization and other values of prof- 
it driven journalism seem to be the main driving forces in coverage of the important social issue.

\section{References}

Bell, P. (1985). Drugs and the Media. Australian Alcohol/Drug Review, 4, $235-242$. http://dx.doi.org/10.1080/09595238580000401

Bright, S., Marsh, A., Smith, L., \& Bishop, B. (2008). What Can We Say about Substance Use? Dominant Discourses and Narratives Emergent from Australian Media. Addiction Research \& Theory, 2, 135-148. http://dx.doi.org/10.1080/16066350701794972

Chermak, S. (1997). The Presentation of Drugs in the News Media: The News Sources Involved in the Construction of Social Problems. Justice Quarterly, 14, 687-718. http://dx.doi.org/10.1080/07418829700093551

Coleman, C. (1993). The Influence of Mass Media and Interpersonal Communication on Societal and Personal Risk Judgments. Communication Research, 20, 611-628. http://dx.doi.org/10.1177/009365093020004006

Craig, R. (1981). Drug Themesin Metropolitan Newspapers: Review and Analysis. Substance Use \& Misuse, 16, $1087-1093$. http://dx.doi.org/10.3109/10826088109038915

Crano, W. D., \& Burgoon, M. (2002). Mass Media and Drug Prevention: Classic and Contemporary Theories and Research. Mahwah, New Jersey, London: LEA.

Deseran, T. A., \& Orcutt, J. D. (2009). The Deconstruction of a Drug Crisis: Media Coverage of Drugs Issues during the 1996 Presidential Campaign. Journal of Drug Issues, 39, 871-891. http://dx.doi.org/10.1177/002204260903900405

Djerf-Pierre, M. (2011).Green Metacycles of Attention: Reassessing the Attention Cycles of Environmental News Reporting 1961-2010. Public Understanding of Science, 4, 499-516.

http://pus.sagepub.com.ezproxy.utlib.ee/content/22/4/495.full.pdf+html? http://dx.doi.org/10.1177/0963662511426819

Edwards, G. (1995). Alcohol Policy and the Public Good. Oxford: Oxford Medical Publications.

Elliott, A., \& Chapman, S. (2000). "Heroin Hell Their Own Making”: Construction of Hero in Users in the Australian Press 1992-97. Drug \& Alcohol Review, 19, 191-201. http://dx.doi.org/10.1080/713659328

EMCDDA (2005). Youth Media: Thematic Papers. Lisbon: European Monitoring Centre for Drugs and Drug Addiction. http://www.emcdda.europa.eu/attachements.cfm/att_34038_EN_TP_Youth_media.pdf

EMCDDA (2014). European Drug Report: Trends and Developments. Luxembourg: Publications Office of the European Union. http://www.emcdda.europa.eu/attachements.cfm/att_228272_EN_TDAT14001ENN.pdf

ESPAD (2012). The 2011 ESPAD Report: Substance Use among Students in 36 European Countries. Stockholm: ESPAD. http://www.espad.org/Uploads/ESPAD_reports/2011/The_2011_ESPAD_Report_FULL_2012_10_29.pdf

Fan, D. (1996). News Media Framing Sets Public Opinion That Drugs Is the Country’s Most Important Problem. Substance Use and Misuse, 31, 1413-1421. http://dx.doi.org/10.3109/10826089609063984

Gonzenbach, W. (1996). The Media, the President and Public Opinion: A Longitudinal Analysis of the Drug Issue, 1962-1991. Mahwah, NJ: Erlbaum.

Hansen, A. (1998). Content Analysis. In A. Hansen, S. Cottle, R. Negrine, \& C. Newbold (Eds.), Mass Communication Research Methods (pp. 91-129). Houndmills: Palgrave Macmillan.

Hellman, M. (2010). From Myth of Marginality to Portrayals of an Addictive Society: Reporting on Addictions in the Finnish Press (1968-2006). Addiction Research \& Theory, 18, 224-242. http://dx.doi.org/10.3109/16066350902836382

Hoffman, L. H., \& Slater, M. D. (2007). Evaluating Public Discourse in Newspaper Opinion Articles: Values-Framing and Integrative Complexity in Substance and Health Policy Issues. Journalism \& Mass Communication Quarterly, 84, 58-74. http://dx.doi.org/10.1177/107769900708400105

Hughes, C. E., Spicer, B., Lancaster, K., Matthew-Simmons, F., \& Dillon, P. (2010). Media Reporting on Illicit Drugs in Australia: Trends and Impacts on Youth Attitudes to Illicit Drug Use. Monograph 19, Drug Policy Modelling Program (DPMP) Monograph Series, Sydney: National Drug and Alcohol Research Centre. http://www.dpmp.unsw.edu.au/DPMPWeb.nsf/resources/Monograph+16.pdf/\$file/DPMP+MONO+19.pdf

Lawrence, G., Bammer, G., \& Chapman, S. (1999). "Sending the Wrong Message”: Analysis of Print Media Reportage of the ACT Heroin Prescription Trial Proposal, August 1997. Australian and New Zealand Journal of Public Health, 24, 254-264. http://dx.doi.org/10.1111/j.1467-842X.2000.tb01565.x

Manning, P. (2006). There's No Glamour in Glue: News and the Symbolic Framing of Substance Misuse. Crime, Media \& Culture, 2, 49-66. http://dx.doi.org/10.1177/1741659006061711

McArthur, M. (1999). Pushing the Drug Debate: The Media’s Role in Policy Reform. Australian Journal of Social Issues, 35, 149-165. 
McComas, K., \& Shanahan, J. (1999). Telling Stories about Global Climate Change: Measuring the Impact of Narratives on Issue Cycles. Communication Research, 26, 30-57. http://dx.doi.org/10.1177/009365099026001003

McCombs, M., \& Reynolds, A. (2002). News Influence on Our Pictures of the World. In J. Bryant, \& D. Zillmann (Eds.), Media Effects: Advances in Theory and Research (2nd ed., pp. 1-18). Mahwah: LEA.

McQuail, D. (2010). McQuail's Mass Communication Theory (6th ed.). London: SAGE.

Ministry of Justice (2015). Registreeritud kuriteod Eestist (Registered Offences in Estonia). http://www.kriminaalpoliitika.ee/et/registreeritud-kuriteod-eestis-2003-2014-excel

Ministry of the Interior (2014). Eesti uimastitarvitamise vähendamisepoliitika. Valgeraamat. (Estonia’s Drug User Educing Policy. The White Paper).

Murji, K. (1998). The Agony and the Ecstasy: Drugs, Media and Morality. In R. Coomber (Ed.), The Control of Drugs and Drug Users: Reasonor Reaction?(pp. 69-85). London: Harwood. http://www.psychedelic-library.org/murji.htm

NIHD (2002). National Report on Drug Situation in Estonia 2001. Tallinn: National Institute for Health Development.

NIHD (2005). Narkomaania Eestis 2005 (Drug Addiction in Estonia 2005). Tallinn: National Institute for Health Development.

NIHD (2009). 2009.a. riiklik raport (2008. a andmed) EMCDDAle REITOXi riiklikult narkoteabekeskuselt (National Report to EMCDDA). Tallinn: National Institute for Health Development.

NIHD (2011). 2011.aasta riiklik raport (2010. Aasta andmed) EMCDDAle REITOXi riiklikult narkoteabekeskuselt. Uus areng, suundumused ja süvainformatsioon valitud teemadel. (National Report to EMCDDA, 2010 Data). Tallinn: National Institute for Health Development. www.tai.ee/terviseandmed/uuringud/download/169

NIHD (2014). 2014. Aasta riiklik raport (2013. Aasta andmed) EMCDDA-le REITOX-i riiklikult narkoteabekeskuselt. Eesti. Uued arengud ja suundumused (National Report to EMCDDA on Drug Situation in Estonia 2014, 2013 Data). Tallinn: National Institute for Health Development (NIHD).

Noto, A. R., Pinsky, I., \& Mastroianni, C. (2006). Drugs in the Brazilian Print Media: An Exploratory Survey of Newspaper and Magazine Stories in the Year 2000. Substance Use \& Misuse, 41, 1263-1276. http://dx.doi.org/10.1080/10826080600754868

OECD (2014). Health at Glance: Europe 2014. http://www.oecd-ilibrary.org/docserver/download/8114211e.pdf?expires=1423235691\&id=id\&accname=guest\&checksu m=0E5F99FFA808CA2BFAD369907622241D

Paimre, M. (2013). Narkoprobleemide kajastamine Eesti ajakirjanduses (1993-2009) (The Representation of Illicit Drugs Related Issues by the Estonian Press, 1993-2009). Academic Dissertation, Jyväskylä: Jyväskylä Studies in Humanities, University of Jyväskylä.

PHARE (1998). National Report Estonia. Sub-Regional Report Estonia. Phare Project on Drug Information System Final Phase. European Commission.

Riffe, D., Lacy, S., \& Fico, F. (2005). Analyzing Media Messages: Using Quantitative Analysis in Research. Mahwah, NJ: Lawrence ErlbaumAssociates.

Saar, A. (2012). Võitlus narkomaaniaga ei saa olla vaid politsei rida. Postimees 18.

Sato, H., \& Campbell, R. (2014). Newspaper Reports on BSE around the Time of the Japan-US Trade Conflicts: Content Analysis of Japanese and US Dailies from 2002 to 2006. Advances in Journalism and Communication, 2, 20-34. http://dx.doi.org/10.4236/ajc.2014.21003

Schäfer, M. S., Ivanova, A., \& Schmidt, A. (2014). What Drives Media Attention for Climate Change? Explaining Issue Attention in Australian, German and Indian Print Media from 1996 to 2010. International Communication Gazette, 76, 152176. http://dx.doi.org/10.1177/1748048513504169

Shanahan, J., \& McComas, K. (1997). Television’s Portrayal of the Environment: 1991-1995. Journalism and Mass Communication Quarterly, 74, 147-159. http://dx.doi.org/10.1177/107769909707400112

Shoemaker, P. J. (1989). Communication Campaigns about Drugs: Governmet, Media and the Public. Hillsdale: Lawrence Erlbaum.

Sznitman, S. R., \& Lewis, N. (2015). Is Cannabis an Illicit Drug or a Medicine? A Quantitative Framing Analysis of Israeli Newspaper Coverage. International Journal of Drug Policy, 26, 446-452.

http://dx.doi.org/10.1016/j.drugpo.2015.01.010

Taylor, S. (2008). Outside the Outsiders: Media Representations of Drug Use. Probation Journal, 55, 369-387. http://dx.doi.org/10.1177/0264550508096493

Törrönen, J. (2004). Finnish Newspapers’ Positions on Drug Policy between 1993 and 2000. Contemporary Drug Problems, $31,59-88$. 
UNODC (2011). World Drug Report 2011. New York: United Nations.

https://www.unodc.org/documents/data-and-analysis/WDR2011/World_Drug_Report_2011_ebook.pdf

UNODC (2013). World Drug Report 2013. New York: United Nations.

http://www.unodc.org/unodc/secured/wdr/wdr2013/World_Drug_Report_2013.pdf

UNODC (2014). World Drug Report 2014. New York: United Nations.

http://www.unodc.org/documents/wdr2014/World_Drug_Report_2014_web.pdf

Watts, R. (2003). “Headlining Heroin”: Policy Change and Reporting the Heroin Problem. Media International Australia, 108, 67-68. 